\title{
Distribution and chromosomal organization of 18S-5.8S-25S and 5S rDNA in Petunia species
}

\author{
A Benabdelmouna, M Abirached-Darmency* \\ Unité de recherche de génétique et d'amélioration des plantes, Inra, BV 1540, 21034 Dijon cedex, France
}

(Received 10 september 1997; accepted 22 october 1997)

\begin{abstract}
Summary - We have analyzed the interspecific variation of the $5 \mathrm{~S}$ rDNA spacer by the polymerase chain reaction in seven Petunia species. The species studied could be separated into two groups with regard to the size of the amplified 5S rDNA variants: one group, with a 460 -bp repeat unit, including $P$ linearis $(2 \mathrm{n}=18)$ and $P$ integrifolia $(2 \mathrm{n}=14)$ and the second group, with a 350 -bp repeat unit, including all the other wild species $(2 \mathrm{n}=14)$ studied and the $P$ hybrida lines. The amplified fragments have been cloned, and used in FISH experiments to determine the number and the location of the $5 \mathrm{~S}$ rDNA units. The chromosomal organization of the $5 \mathrm{~S}$ rDNA enabled us to distinguish a group of coloured flowered species with one locus adjacent to the major 18S-5.8S-25S rDNA locus on chromosome II, and a group of white flowered species with an additional locus in the centromeric region of a metacentric chromosome (IV/VII). FISH analysis also revealed four hybridization sites of 18S-5.8S-25S rDNA in the majority of the Petunia species studied. Only $P$ linearis and $P$ parviflora $(2 \mathrm{n}=18)$ showed two hybridization sites. The four sites of 18S-5.8S-25S rDNA are transcriptionally active as shown by their expression pattern in interphase nuclei. Our FISH results combined with PCR amplification and RFLP studies of the rDNA clusters give a new insight into the phylogenetic relationships between wild species and the $P$ hybrida lines.
\end{abstract}

\section{Petunia species / PCR / 5S and 18S-5.8S-25S rDNA / FISH}

\begin{abstract}
Résumé - Distribution et organisation chromosomique des gènes ribosomiques $18 \mathrm{~S}-5.8 \mathrm{~S}-25 \mathrm{~S}$ et $5 \mathrm{~S}$ chez Petunia. Nous avons analysé la variation interspécifique de l'espaceur 5S ADNr par la tehnique d'amplification génique (PCR) dans sept espèces de Petunia. Les espèce étudiées peuvent être séparées en deux groupes suivant la taille des variants $5 \mathrm{~S}$ ADNr amplifiés : un groupe avec une unité de répétition de 460 pb comprenant $P$ linearis ( $2 n=18)$ et $P$ integrifolia $(2 n=14)$, et un deuxième groupe avec une unité de répétition de $350 \mathrm{pb}$ comprenant toutes les autres espèces sauvages $(2 n=14)$ étudiées et les lignées de $P$ hybrida. Les fragments amplifiés ont été clonés et ont servi de sondes pour l'hybridation in situ fluorescente afin de déterminer le nombre et la localisation des unités 5S. L'organisation chromosomique du 5S ADNr nous a permis de distinguer un groupe d'espèces à fleurs colorées avec un locus adjacent au locus majeur 18S-5.8S-25S ADNr du chromosome II et un groupe d'espèces à fleurs blanches avec un locus supplémentaire situé dans la région centromérique d'un chromosome métacentrique (IV/VII). L'hybridation in situ fluorescente a également révélé quatre sites d'hybridation pour le 18S-5.8S-25S ADNr dans la majorité des espèces de Petunia étudiées. Seuls $P$ linearis et P parviflora $(2 n=18)$ ont montré deux sites d'hybridation. L'observation des pattern d'expression dans les noyaux interphasiques nous a permis de montrer que les quatre sites d'ADNr18S-5.8S-25S sont en activité de transcription. Les résultats obtenus en hybridation in situ fluorescente ainsi que les amplifications par PCR et les études RFLP des ADNr nous ont conduits à une nouvelle approche des relations phylogéniques entre les espèces sauvages et les lignées de $P$ hybrida.
\end{abstract}

Petunia / PCR / ADNr 5S / ADNr 18s-5.8S-25S / hybridation in situ

Article communicated by Hervé Thiellement (Versailles)

* Correspondence and reprints

Tel: (33) 03806331 42; fax: (33) 03806332 63; e-mail : mona@ chassagne.epoisses.inra.fr 


\section{INTRODUCTION}

The structure, organization and evolution of the 18S-5.8S-25S and 5S rDNA multigene families have been studied in detail in several plant species. The 18S-5.8S-25S ribosomal RNA genes (rDNA) are present in several hundreds of tandemly repeated units of the three genes with intergenic spacers, organized in one or more clusters within the genome (Appels et al, 1980; Saghai-Maroof et al, 1984; Flavel, 1986; Rogers and Bendich, 1987). The genes coding for the $5 \mathrm{~S}$ ribosomal RNA (5S rDNA) are also present in multiple copies per genome. They are arranged head to tail and are separated from each other by simple spacers (Appels and Honeycut, 1986). As in all higher eukaryotes, the $5 \mathrm{~S}$ and $18 \mathrm{~S}-5.8 \mathrm{~S}-25 \mathrm{~S}$ rDNA are organized in separate loci. The 18S5.8S-25S rDNA repeat unit and the 5S rDNA unit of Petunia hybrida have both been characterized (Waldron et al, 1983; Frasch et al, 1989). In situ hybridization revealed two 18S-5.8S-25S rDNA clusters and one 5S rDNA cluster localized on the short arm of chromosome II (Montijn et al, 1994; Montijn, 1997).

RFLP studies of rDNA have shown variation between $P$ hybrida lines and wild species by using a heterologous probe. They revealed three length variants in the 5S rDNA (Zeboudj et al, 1994; Kabbaj et al, 1995).

We aimed to study the polymorphism in the chromosomal organization of the rDNA repeat units in $P$ hybrida and its putative parents. The number of $5 \mathrm{~S}$ rDNA loci and their chromosomal localization with respect to the $18 \mathrm{~S}-5.8 \mathrm{~S}-25 \mathrm{~S}$ rDNA loci were analyzed, by fluorescent in situ hybridization (FISH), in six Petunia wild species, two F1 hybrids and four $P$ hybrida lines. The homologous $5 \mathrm{~S}$ rDNA probes were generated by PCR amplification using 'universal' primers. The amplification profiles obtained and the $5 \mathrm{~S}$ rDNA restriction polymorphism in the different genotypes were also analyzed.

Our ultimate aim was to establish the phylogenetic relationships inside the genus Petunia based on the PCR amplified 5S rRNA genes, their restriction polymorphism and their physical distribution in the putative parental species of the interspecific hybrid $P$ hybrida and in some $P$ hybrida lines.

\section{MATERIALS AND METHODS}

\section{Plant materials}

The Petunia species and the $P$ hybrida lines used in this study, as well as their characteristics, are listed in table I. Plant growth occurred in a greenhouse at $20^{\circ} \mathrm{C}$ for a $16-\mathrm{h}$ day and $15^{\circ} \mathrm{C}$ at night.

Table I. List of the main traits and origins of the plant material.

\begin{tabular}{|c|c|c|c|c|}
\hline Species & Code & $2 n=$ & Corolla colour & Origin \\
\hline$P$ linearis & S11 & 18 & violet pink & IGA S 11 \\
\hline$P$ parviflora & & 18 & purple & USA Michigan \\
\hline$P$ integrifolia & $\mathrm{S} 13$ & 14 & violet pink & Dijon S13 \\
\hline$P$ inflata & D1 & 14 & purple & Paris, Museum \\
\hline$P$ axillaris & MI & 14 & white & USA Cornell \\
\hline$P$ parodii & & 14 & white & USA Michigan \\
\hline \multirow[t]{5}{*}{ Phybrida } & Lines & 14 & & \\
\hline & ST40 & & clear pink & R40 (IGA) \\
\hline & TB $1-3$ & & purple & 'Velours rouges' \\
\hline & TLH7 & & violet-white & 'Rose du ciel' $\times P$ axillaris \\
\hline & TLV1 & & clear violet & $\mathrm{T} 1 \times \mathrm{g}$ \\
\hline \multirow[t]{3}{*}{ F1 hybrid } & code & 14 & & \\
\hline & $\mathrm{M} 1 \times \mathrm{S} 13$ & & clear violet & $P$ axillaris $\times P$ integrifolia \\
\hline & $\mathrm{D} 1 \times \mathrm{M} 1$ & & clear violet & $P$ inflata $\times P$ axillaris \\
\hline
\end{tabular}

USA Michigan: Sink, KC, East Lansing (USA). USA Cornell: M Hanson, Cornell University. IGA: Institute of Genetics, Amsterdam (the Netherlands). 


\section{Chromosome preparation}

\section{Synchronization of mitosis}

Root-tips of about $2 \mathrm{~cm}$ in length were synchronized by the method of Pan et al (1993) with minor modifications. The roots were placed in Hoagland solution (Gamborg et al, 1968) supplemented with $1.25 \mathrm{mM}$ hydroxyurea (HU) for $18 \mathrm{~h}$. After this period, they were rinsed three times and then transferred to fresh medium without HU. After $8 \mathrm{~h}$, excised root-tips were treated with $0.05 \%$ colchicine for $90 \mathrm{~min}$ to accumulate metaphases. All treatments were performed at $27{ }^{\circ} \mathrm{C}$ in the dark. After rinsing with distilled water, the root-tips were fixed in $3: 1 \quad(\mathrm{v} / \mathrm{v}) 100 \%$ ethanol/acetic acid and stored at $-20^{\circ} \mathrm{C}$ until use.

\section{Preparation of metaphase spreads}

The fixed root-tips were rinsed with distilled water and then incubated at $37{ }^{\circ} \mathrm{C}$ in an enzyme mixture $(0.25 \%$ pectolyase $\mathrm{Y}-23,3 \%$ cellulase onozuka $\mathrm{R}-10,0.4 \mathrm{M}$ sorbitol, $\mathrm{pH} 5.5$ ) for $90 \mathrm{~min}$. After incubation the roottips were transferred to fresh cold $45 \%$ acetic acid for $15 \mathrm{~min}$. A single root-tip was transferred in a drop of $45 \%$ acetic acid onto a cleaned slide before gentle squashing. The cover slips were removed by immersing slides in liquid nitrogen and the preparations were dehydrated for $10 \mathrm{~min}$ each in a graded series of $70 \%$, $95 \%$ and absolute ethanol at room temperature. The air-dried slides were stored at room temperature, up to 1 month, in sealed containers until use.

\section{PCR amplification of the 5S rDNA and cloning of the amplification products}

Amplification of the $5 \mathrm{~S}$ rDNA was obtained by the method of Cox et al (1992) with some modifications. Total plant DNA was extracted from young growing leaves according to the method of Bernatzky and Tanksley (1986). Templates for PCR consisted of total genomic DNA. The standard amplification mixture $(50 \mu \mathrm{L})$ contained $60 \mathrm{ng}$ genomic template DNA, $10 \mathrm{ng}$ of each primer, $500 \mu \mathrm{M}$ each of dATP, dCTP, dGTP and dTTP (Pharmacia), $5 \mu \mathrm{L}$ reaction buffer (170 mM $\left(\mathrm{NH}_{4}\right)_{2} \mathrm{SO}_{4}, 30 \mathrm{mM} \mathrm{MgCl} 2,670 \mathrm{mM}$ Tris$\mathrm{HCl}, \mathrm{pH} 8.8$ ) and 2.5 units Taq polymerase (BRL). Thirty amplification cycles were performed on a PTC 200 thermal-cycler (MJ Research). Each cycle consisted of denaturation at $94{ }^{\circ} \mathrm{C}$ for $1 \mathrm{~min}$, annealing at $60{ }^{\circ} \mathrm{C}$ for $1 \mathrm{~min}$ and primer extension at $72{ }^{\circ} \mathrm{C}$ for 2 min. The primers used were PIII and PIV established by Cox et al (1992). The sequences of these two primers were as follows:

PIII: 5'-GAGAGTAGTACATCGATGGG-3' (20-mer);

PIV: 5'-GGAGTTCTGACGGGATCCGG-3' (20-mer).
Amplification products were separated by electrophoresis on $3 \%$ agarose gels made up in $1 \times$ TAE (40 mM Tris-acetate, $1 \mathrm{mM}$ EDTA). The gels were loaded with $15 \mu \mathrm{L}$ amplification mixture and electrophorezed for $2 \mathrm{~h}$ at $10 \mathrm{~V} \mathrm{~cm}^{-1}$. They were then stained with ethidium bromide and visualized using an ultraviolet transilluminator.

The PCR gels were transferred to nylon membranes (Amersham, $\mathrm{N}^{+}$) according to Southern (1975) and the filters hybridized with the pBG13 probe which contains ten copies of the 5S rDNA unit from flax (Goldsbrough et al, 1981; Goldsbrough et al, 1983). This clone was kindly provided by N Ellis. The pBG13 probe was labelled with ${ }^{32} \mathrm{P}$-dCTP $(3000 \mathrm{mCi} / \mathrm{mL})$ using a random primed DNA labelling kit (Boehringer) and hybridized to the membranes in hybridization buffer $(6 \times \mathrm{SSC}, 5 \times$ Denhardt's, $0.1 \%$ SDS ) at $65{ }^{\circ} \mathrm{C}$. After overnight hybridization, the filters were washed for $2 \times 15 \mathrm{~min}$ at $65^{\circ} \mathrm{C}$ in $(2 \times \mathrm{SSC}, 0.1 \% \mathrm{SDS}), 2 \times 15 \mathrm{~min}$ at $65{ }^{\circ} \mathrm{C}$ in $(0.5 \times \mathrm{SSC}, 0.1 \% \mathrm{SDS})$, and then $2 \times 15 \mathrm{~min}$ at $65^{\circ} \mathrm{C}$ in $(0.1 \times \mathrm{SSC}, 0.1 \% \mathrm{SDS})$. Autoradiograms were obtained after overnight to 96 -h exposure at $-70^{\circ} \mathrm{C}$.

Each amplification product (amplified using the primers PIII/PIV under the conditions described above) was extracted with phenol chloroform and ethanol precipitated. The pellet was washed twice in $70 \%$ ethanol and dried under vacuum before being resuspended in $10 \mu \mathrm{L}$ TE buffer $(10 \mathrm{mM}$ Tris- $\mathrm{HCl}$, pH 8.0, 0.1 mM EDTA, pH 8.0). Each amplification product was cloned, without further digestion, in pT7 Blue T-Vector (Novagen) following the manufacturer's instructions and transformed into $E$ coli XL1-blue. Recombinant clones were plated onto selective media and screened by the blue/white method. Minipreparations of positive clones were prepared according to Maniatis et al (1982) and insert sizes were checked by PCR using the PIII/PIV primer combination before being sequenced using the improved dideoxy chain terminating method described by Murphy and Kavanagh (1988). The obtained sequences were compared between themselves and with the published $P$ hybrida 5 S rDNA sequence (Frasch et al, 1989) using the Sequence Analysis Software of the Genetics Group of the University of Wisconsin.

\section{Southern hybridization analysis}

Total genomic DNA from the chosen Petunia species, $P$ hybrida lines and the $\mathrm{F} 1$ hybrid $P$ inflata $\mathrm{D} 1 \times P$ axillaris M1 were digested overnight with EcoRI, BamHI and DraI (BRL). Ten units of enzymes per microgram DNA at $37^{\circ} \mathrm{C}$ were used according to the manufacturer's instructions. Agarose (1\%) electrophoresis took place in TAE (Maniatis et al, 1982). The digested DNAs were transferred to nylon membranes (Amersham, hybond $\mathrm{N}^{+}$) and hybridized with the cloned $5 \mathrm{~S}$ rDNA. Labelling of the probes, hybridization and post hybridization washes were carried out as described above. 


\section{FISH analysis}

\section{DNA probes}

For the 18S-5.8S-25S rDNA probes we used either the 6.1-kb EcoRI fragment from sunflower kindly provided by P Heizmann (Choumane and Heizman, 1988) or the 2.8-kb NS3/NLD22 amplification product from Pea [NS3 primer: White et al (1990); NLD22 primer: Van Tuinen et al (1997)]. The 6.1-kb EcoRI fragment from sunflower carries an almost complete $18 \mathrm{~S}$ fragment, the IGS and a small part of the $25 \mathrm{~S}$ fragment. The 2.8-kb NS3/NLD22 amplification product from pea carries a part of $18 \mathrm{~S}$ fragment, the complete ITS1, ITS2 and 5.8S fragments and a large part of the $25 \mathrm{~S}$ fragment. Both probes were labelled by means of nick translation with digoxigenin-11-dUTP following the supplier's instructions. The Petunia 5S rDNA probes were from the cloned PCR product obtained by using the PIII/PIV primer combination. These probes were labelled by digoxigenin-11-dUTP either by means of nick translation (BRL) or by PCR amplification using the same primers according to the supplier's instructions.

\section{In situ hybridization}

The in situ hybridization reaction was modified from Montijn et al (1994). The hybridization mixture was prepared to a final concentration of $10 \mathrm{ng} / \mu \mathrm{L}$ digoxigenin labelled probe, $600 \mathrm{ng} / \mu \mathrm{L}$ of autoclaved herring sperm DNA, $2 \times$ SSC, $10 \%$ dextran sulfate, $0.1 \%$ SDS, 1 mM EDTA, $1 \times$ Denhardt's and $50 \%$ deionized formamide.

Slides were incubated with $100 \mu \mathrm{L}$ of Rnase $\mathrm{A}$ $(100 \mu \mathrm{g} / \mathrm{mL}$ in $2 \times \mathrm{SSC})$ for $60 \mathrm{~min}$ at $37^{\circ} \mathrm{C}$ under a plastic coverslip in a humid chamber. After $3 \times 5 \mathrm{~min}$ washes in $2 \times \mathrm{SSC}$ and $5 \mathrm{~min}$ in proteinase $\mathrm{K}$ buffer (20 mM Tris- $\mathrm{HCl}, \mathrm{pH} \mathrm{7.5,2 \textrm {mM } \mathrm { CaCl }}$ ) at $37^{\circ} \mathrm{C}$, slides were incubated with $100 \mu \mathrm{L}$ of proteinase $\mathrm{K}$ solution $(1 \mu \mathrm{g} / \mathrm{mL})$ for $10 \mathrm{~min}$ at $37{ }^{\circ} \mathrm{C}$ and $5 \mathrm{~min}$ in proteinase K stop-buffer ( $20 \mathrm{mM}$ Tris- $\mathrm{HCl}, \mathrm{pH} 7.5,2$ $\mathrm{mM} \mathrm{CaCl}, 50 \mathrm{mM} \mathrm{MgCl}{ }_{2}$ ). Chromosome preparations were then fixed in ethanol/acetic acid 3/l-V/V for $10 \mathrm{~min}$ at room temperature, rinsed $3 \times 5 \mathrm{~min}$ in $2 \times \mathrm{SSC}$, dehydrated in 70,95 and $100 \%(\mathrm{v} / \mathrm{v})$ ethanol and air dried. The hybridization mixture was denatured at $70{ }^{\circ} \mathrm{C}$ for $10 \mathrm{~min}$ and immediately quenched in ice for $5 \mathrm{~min}$, and $20 \mu \mathrm{L}$ was then applied on each slide. A plastic cover slip was applied on the preparation and sealed with rubber solution.

The chromosomes and the hybridization mixture were denatured at $80{ }^{\circ} \mathrm{C}$ for $10 \mathrm{~min}$, and incubated overnight at $37{ }^{\circ} \mathrm{C}$ in a humid chamber. After hybridization, the rubber solution was peeled off and cover slips were removed by dipping the slides into $2 \times$ SSC at $37^{\circ} \mathrm{C}$. The slides were then washed twice in $50 \%$ formamide, $2 \times \mathrm{SSC}$ for $10 \mathrm{~min}$ each at $42^{\circ} \mathrm{C}$, twice in $2 \times \mathrm{SSC}$ for $10 \mathrm{~min}$ each at $37^{\circ} \mathrm{C}$, twice in $0.1 \times \mathrm{SSC}$ for $10 \mathrm{~min}$ each at $37^{\circ} \mathrm{C}$ and in $2 \times \mathrm{SSC}$ for $10 \mathrm{~min}$ at room temperature.
Hybridization sites were detected using a three-step immunodetection procedure (Boehringer). The slides were first washed in the detection buffer (PBS, $0.2 \%$ Tween 20) for $5 \mathrm{~min}$ at room temperature, and blocked with $200 \mu \mathrm{L} \mathrm{5 \%}$ BSA (Serum Bovine AlbuminFraction V, Sigma) in detection buffer for $45 \mathrm{~min}$ at $37^{\circ} \mathrm{C}$. The blocking solution was drained off and the slides incubated with $0.5 \mu \mathrm{g} / \mathrm{mL}$ mouse monoclonal anti-Dig for $45 \mathrm{~min}$ at $37^{\circ} \mathrm{C}$ in a moist chamber. After $3 \times 5$ min washes at room temperature, the slides were incubated with $2 \mu \mathrm{g} / \mathrm{mL}$ Dig-conjugated sheep antimouse antibody for $45 \mathrm{~min}$ at $37^{\circ} \mathrm{C}$. After $3 \times 5 \mathrm{~min}$ washes, the slides were incubated with $2 \mu \mathrm{g} / \mathrm{mL}$ fluorescein-conjugated sheep anti-Dig antibody for $45 \mathrm{~min}$ at $37{ }^{\circ} \mathrm{C}$. The final washes were performed with $4 \times \mathrm{SSC}$ for $2 \times 3 \mathrm{~min}$ at room temperature in the dark.

Chromosomes were counter-stained with $5 \mu \mathrm{g} / \mathrm{mL}$ in $2 \times \mathrm{SSC}$ propidium iodide for $10 \mathrm{~min}$ at room temperature followed by washing in $2 \times$ SSC. The drained slides were mounted in an antifade solution $(90 \%$ glycerol in PBS, $1 \mathrm{mg} / \mathrm{mL}$-phenylene diamine), covered by a $24 \times 34 \mathrm{~mm}$ cover slips and stored at $4{ }^{\circ} \mathrm{C}$ for 1 day to stabilize the fluorescence.

Chromosome preparations were analyzed using a Leica DMRB epifluorescent microscope with an appropriate filter (13: excitation 488, emission 520). Photographs were taken on Fujicolor 400 colour slide film. Some observations were made on a Leica confocal scanning microscope (Leica CLMS, Heidelberg, Germany) with appropriate filters. For each sample, eight to ten metaphases were analyzed.

\section{RESULTS}

\section{Physical localization of 18S-5.8S-25S}

The number of rDNA clusters for each species has been determined on metaphase chromosomes and interphase nuclei by in situ hybridization with the 18S-5.8S-25S rDNA probes. Four fluorescent hybridization sites were observed in the $P$ hybri$d a$ lines and in the wild species with $2 \mathrm{n}=14$ chromosomes. The two strongest signals indicating the sites of the major rDNA cluster were located at the NOR region of chromosome II, and the second pair of hybridization signals corresponded to the minor NOR region of chromosome III with less visible secondary constriction (fig $1 \mathrm{a}-\mathrm{c}, \mathrm{e}-\mathrm{j}$ ). In the interphase nuclei the transcribed rDNA was visualized as a track of dispersed punctuate hybridization spots which connected the homologous sites (fig $1 \mathrm{~h}, \mathrm{j}$ ). In the two Petunia species with $2 \mathrm{n}=18$ chromosomes, $P$ linearis and $P$ parviflora, only two hybridization signals were observed at the distal part of a nonidentified chromosome pair (fig 1d). 


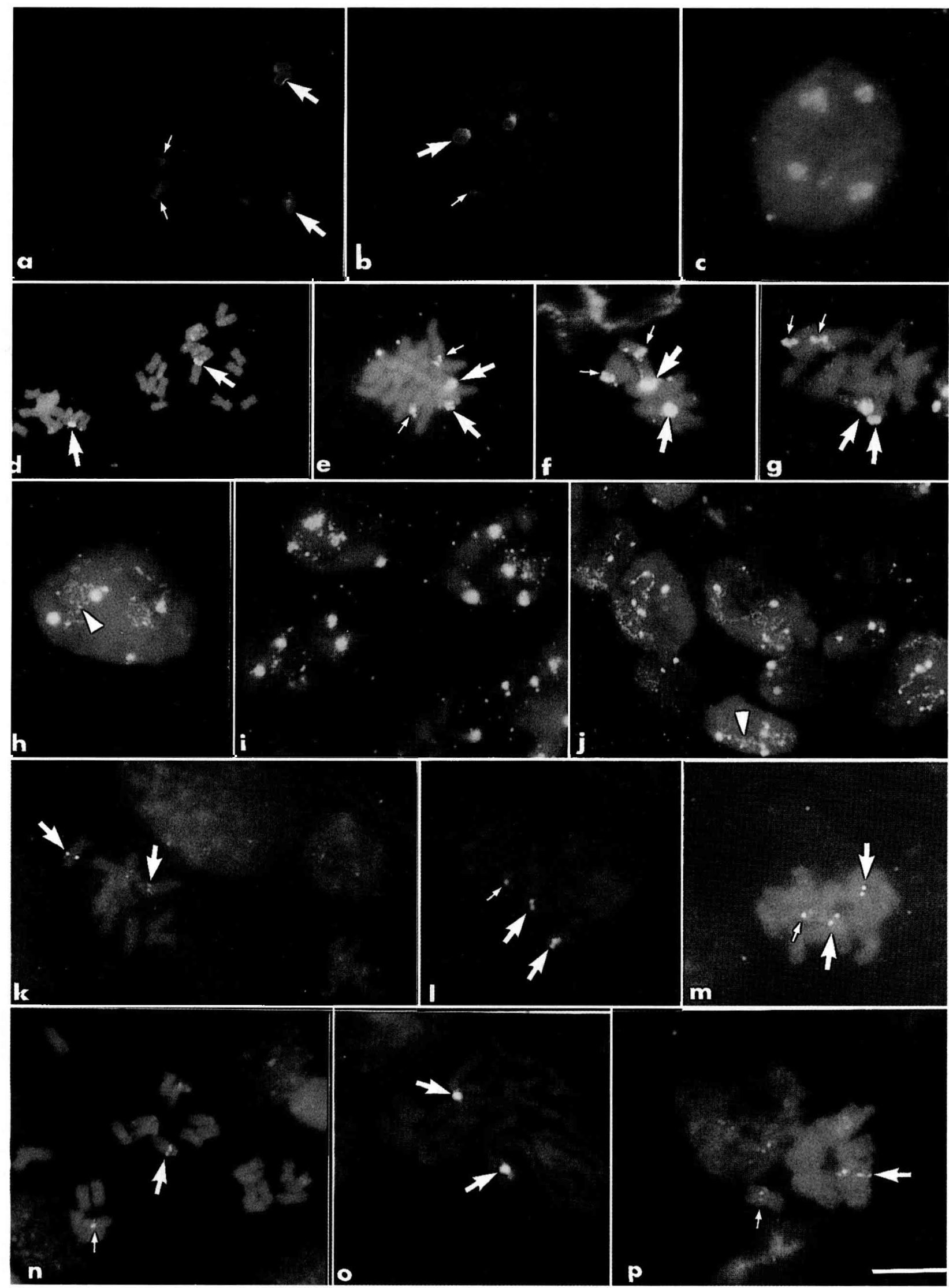

Fig 1. Fluorescent in situ hybridization of rDNA probes to metaphase chromosomes and interphase nuclei in Petunia species. Micrographs (a-j) show the 18S-5.8S-25S rDNA hybridization sites (green and yellow spots) in $P$ axillaris (a), $P$ inflata $\times P$ axillaris (b and h), $P$ parodii (c), P linearis (d), $P$ integrifolia (e), $P$ hybrida ST40 (f), $P$ hybrida TLV1 (g), $P$ hybrida TLH7 (i) and $P$ hybrida TB1-3 (j). On the metaphase plates, small arrows indicate the minor sites carried by chromosome III and large arrows indicate the major sites carried by chromosome II. In the interphase nuclei $(\mathrm{h}, \mathrm{j})$ four hybridization signals were detected with a variable number of small hybridization spots corresponding to the transcriptionally active rDNA gene clusters (arrowheads).

Micrographs $(\mathrm{k}-\mathrm{p})$ show the $5 \mathrm{~S}$ rDNA hybridization sites (yellow spots) revealed by the PIII/PIV amplified products in $P$ inflata (k), $P$ inflata $\times P$ axillaris ( 1 and $\mathrm{m}) P$ parodii $(\mathrm{n}), P$ hybrida ST40 (o) and $P$ hybrida TLH7 (p). Large arrows indicate the $5 \mathrm{~S}$ rDNA locus carried by chromosome II while the small arrows indicate the second locus carried by the meta to sub-metacentric chromosomes (IV/VIII). Bar equals $6 \mu \mathrm{m}$ in $(\mathrm{a}-\mathrm{c}) ; 7 \mu \mathrm{m}$ in $(\mathrm{h}, \mathrm{p})$; and $8 \mu \mathrm{m}$ in $(\mathrm{d}-\mathrm{g}, \mathrm{i}-\mathrm{o})$. 
BamHI

\section{BamHI}

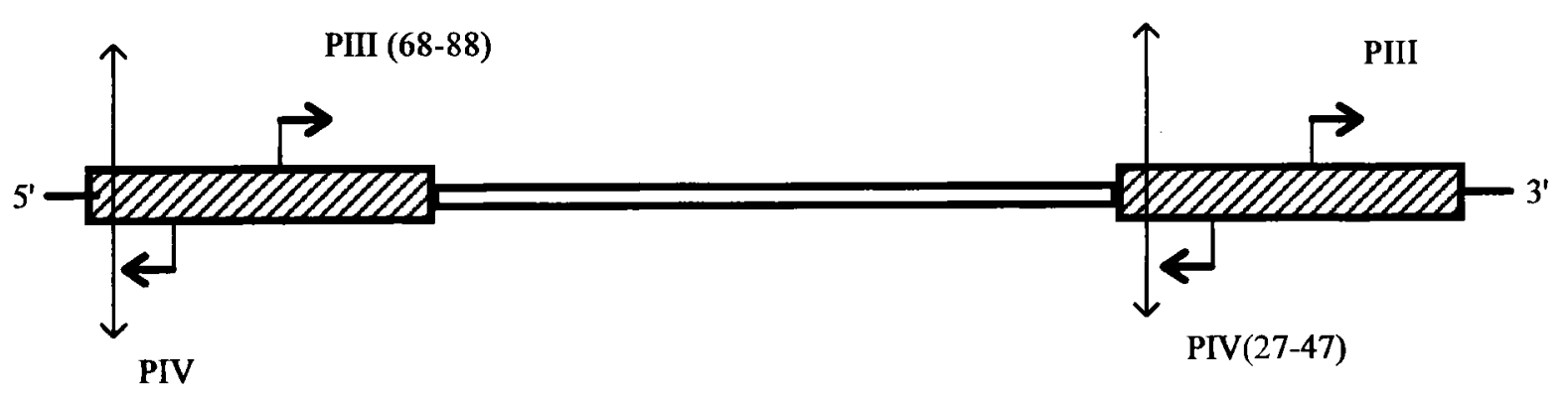

$120 \mathrm{bp}$

$230-340 \mathrm{bp}$

Fig 2. The position from which the primers initiate DNA amplification in the $5 \mathrm{~S}$ rDNA repeating unit is shown. Shaded squares represent the coding region and open squares the non-transcribed spacer region.

\section{Physical localization of 5S rDNA}

\section{Characteristics of PCR amplified 5S rDNA}

The positions of the primers PIII and PIV (fig 2) were established by comparison of the published $P$ hybrida 5S rDNA sequence and the two primer sequences using the Research program (Amersham). As expected, the two primer positions found in the Petunia 5S rDNA were identical to those found in pea by Cox et al (1992), namely from nucleiotide 27 to 47 for PIV and from nucleotide 68 to 88 for PIII.

The results of PCR amplification of the $5 \mathrm{~S}$ rDNA in four wild Petunia species, four $P$ hybri$d a$ lines and two F1 hybrids are shown (fig 3 ). Two size classes of repeat units corresponding to two groups of genotypes were observed. The first group including $P$ linearis $(2 \mathrm{n}=18)$ and $P$ integrifolia $(2 \mathrm{n}=14)$, was characterized by a repeat unit of approximately $460 \mathrm{bp}$ and its multimers (fig 3, lanes 2,3). The 350-bp repeat unit and its multimers characterized the second group which included $P$ axillaris, $P$ parodii, $P$ inflata $(2 \mathrm{n}=14)$ and the four $P$ hybrida lines $(2 \mathrm{n}=14)$ analysed (fig 3, lanes 4-6, 9-12). As expected, in the F1 hybrids the amplification profiles corresponded to those obtained for each parent. In the F1 hybrid $P$ inflata $\times P$ axillaris (fig 3, lane 7) a single 350bp unit and its multimers were amplified but in the F1 hybrid $P$ axillaris $\times P$ integrifolia (fig 3 , lane 8) two bands of 350 and $460 \mathrm{bp}$ and their respective multimers were obtained.

In order to verify the 5S rDNA origin of the PIII/PIV amplified fragments, they were hybridized with the $\mathrm{pBG} 13$ probe, which revealed a banding pattern corresponding exactly to the pattern obtained with the PCR amplification (fig 4). These results confirmed the specificity of the PIII/PIV amplification and the 5S rDNA origin of the amplified bands. The amplified 460-bp and 350 -bp repeat units were sequenced. As shown in figure 5 , the 460 -bp sequence, which revealed high homology with the published $P$ hybrida $5 \mathrm{~S}$ rDNA sequence, differed from the 350 -bp sequence by an extra DNA of $110 \mathrm{bp}$.

\section{$\begin{array}{llllllllllllll}1 & 2 & 3 & 4 & 5 & 6 & 7 & 8 & 9 & 10 & 11 & 12 & 13 & 14\end{array}$}

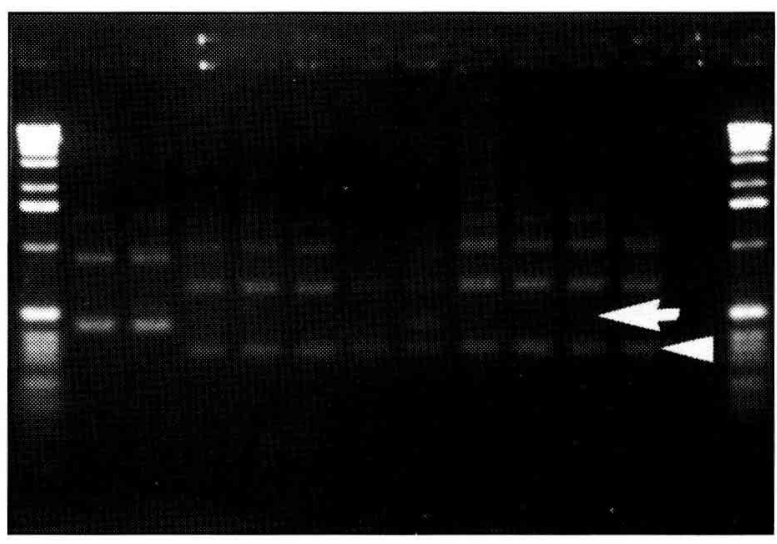

Fig 3. Gel-fractionated products of the PCR reaction using the PIII/PIV primers. The 350- and 460-bp units are marked with an arrowhead and an arrow, respectively. Lane 1 and 14 represent the 1-kb ladder (BRL); lane 2, P linearis; lane 3, $P$ integrifolia; lane $4, P$ axillaris; lane $5, P$ parodii; lane 6 , $P$ inflata, lane $7, P$ inflata $\times P$ axillaris; lane $8, P$ axillaris $\times$ $P$ integrifolia; lane 9, ST40; lane 10, TB1-3; lane 11, TLH7; lane 12, TLV1; and lane 13, negative control. 
$\begin{array}{llllllllllllll}1 & 2 & 3 & 4 & 5 & 6 & 7 & 8 & 9 & 10 & 11 & 12 & 13 & 14\end{array}$

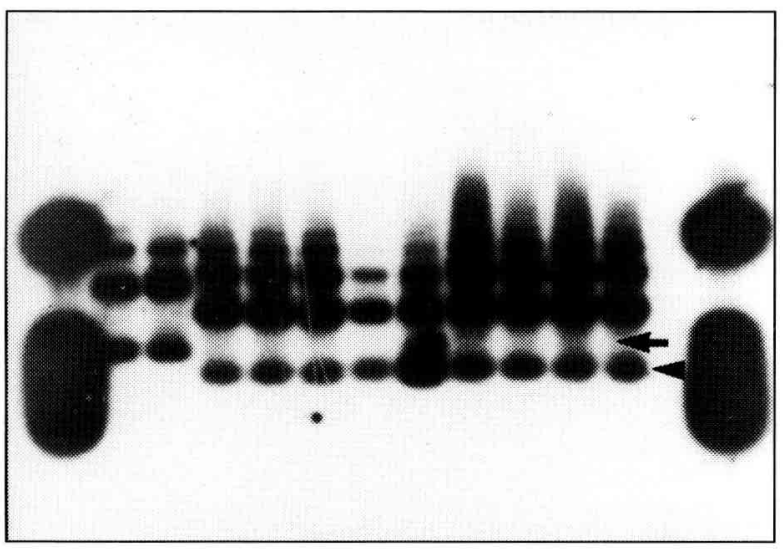

Fig 4. Hybridization profile of the transferred gel shown on figure 3 with the probe $p B G 13$. The $350-$ and $460-b p$ revealed bands are marked with an arrowhead and an arrow, respectively.

The hybridization patterns obtained with the two cloned 5S rDNA amplified units (350 bp and $460 \mathrm{bp}$ ) against total digested genomic DNA are shown in figure 6 . For each genotype, the two amplified 5S rDNA units produced the same ladders of restriction fragments on the three DNA digestions. These ladders appeared clearly in the BamHI digestion (fig 6B) and more weakly with Dral (fig 6C). The EcoRI digest (fig 6A) showed a ladder only for $P$ linearis. The periodicity of the ladders was approximately $500 \mathrm{bp}$ in $P$ linearis $(2 \mathrm{n}=18), 460 \mathrm{bp}$ in $P$ integrifolia $(2 \mathrm{n}=14)$ and 350 bp in $P$ axillaris, $P$ inflata, $P$ parodii and in the $P$ hybrida lines (ST40, TB1-3, TLH7 and TLV1).

\section{S rDNA in situ hybridization}

In the $2 \mathrm{n}=14$ Petunia species including $P$ integrifolia, $P$ inflata and the $P$ hybrida lines ST40, TB1-3 and TLV1, two 5S rDNA hybridization sites were detected on the short arm of chromosome pair II between the NOR region and the centromere (fig $1 \mathrm{k}, \mathrm{o}$ ). Two $5 \mathrm{~S}$ rDNA hybridization sites were also detected in a sub-terminal position on a chromosome pair in $P$ linearis and $P$ parviflora with $2 \mathrm{n}=18$. However, in $P$ axillaris, $P$ parodii $(2 \mathrm{n}=14)$ and the $P$ hybrida line TLH7 two additional signals were localized near the centromere on a pair of meta to submetacentric chromosomes probably corresponding to chromosome pair IV or VII (fig $1 \mathrm{n}, \mathrm{p}$ ).
In the F1 hybrid $P$ inflata $\times P$ axillaris, as expected, three hybridization sites were observed in both interphase nuclei and metaphase chromosomes (fig $1 \mathrm{l}, \mathrm{m}$ ). Two sites were carried by the satellited chromosome pair II, and the third pericentromeric site was carried by the meta to submetacentric chromosome IV or VII. Figure 7 summarizes the distribution of $5 \mathrm{~S}$ rDNA hybridization sites in the Petunia species $(2 n=14)$.

\section{DISCUSSION}

This study reports the first data on 5S rDNA PCR amplification in Petunia species. The sequenced amplification products were used to analyse the restriction length polymorphism of the $5 \mathrm{~S}$ rDNA and to detect by FISH the number of clusters as well as their chromosomal localization. Our FISH results also revealed a variable number of $18 \mathrm{~S}$ 5.8S-25S rDNA loci in $P$ linearis and $P$ parviflo$r a(2 n=18)$ in comparison with the other studied Petunia species and $P$ hybrida lines $(2 \mathrm{n}=14)$.

The PCR amplifications using 'universal' primers PIII and PIV combined with the hybridization results with the heterologous $5 \mathrm{~S}$ rDNA probe from flax and the sequencing analysis, clearly showed the $5 \mathrm{~S}$ rDNA origin of the amplified products and their size polymorphism. The species studied here could be separated into two groups according to the size of the amplified 5S rDNA variants: one group, with a $460-\mathrm{bp}$ repeat unit included $P$ linearis $(2 \mathrm{n}=18)$ and $P$ integrifolia $(2 \mathrm{n}=14)$ and the second group, with a 350 -bp repeat unit, included all the other $(2 \mathrm{n}=14)$ Petunia species ( $P$ axillaris, $P$ inflata, $P$ parodii and the $P$ hybrida lines ST40, TB1-3, TLH7 and TLV1). Interspecific DNA variation was also found between wheat and different Brachypodium species using the 5S rDNA amplification protocol (Cox et al, 1992). Comparison of the amplified 460-bp repeat unit, 350-bp repeat unit and the published $P$ hybrida $5 \mathrm{~S}$ rDNA sequences (phrn5s1, Frash et al, 1989) revealed a high homology between them. It showed that the 460-bp repeat unit corresponded to phrn5s 1 with a coding sequence of $120 \mathrm{bp}$ and a spacer sequence of $340 \mathrm{bp}$. This 460-bp repeat unit differed from the 350-bp repeat unit mainly by an extra DNA of $110 \mathrm{bp}$ in the spacer region. As mentioned by Cox et al (1992) it seems more probable that the shorter spacers were derived from the longer ones, as a result of deletions, rather than vice-versa by insertions or duplications. 


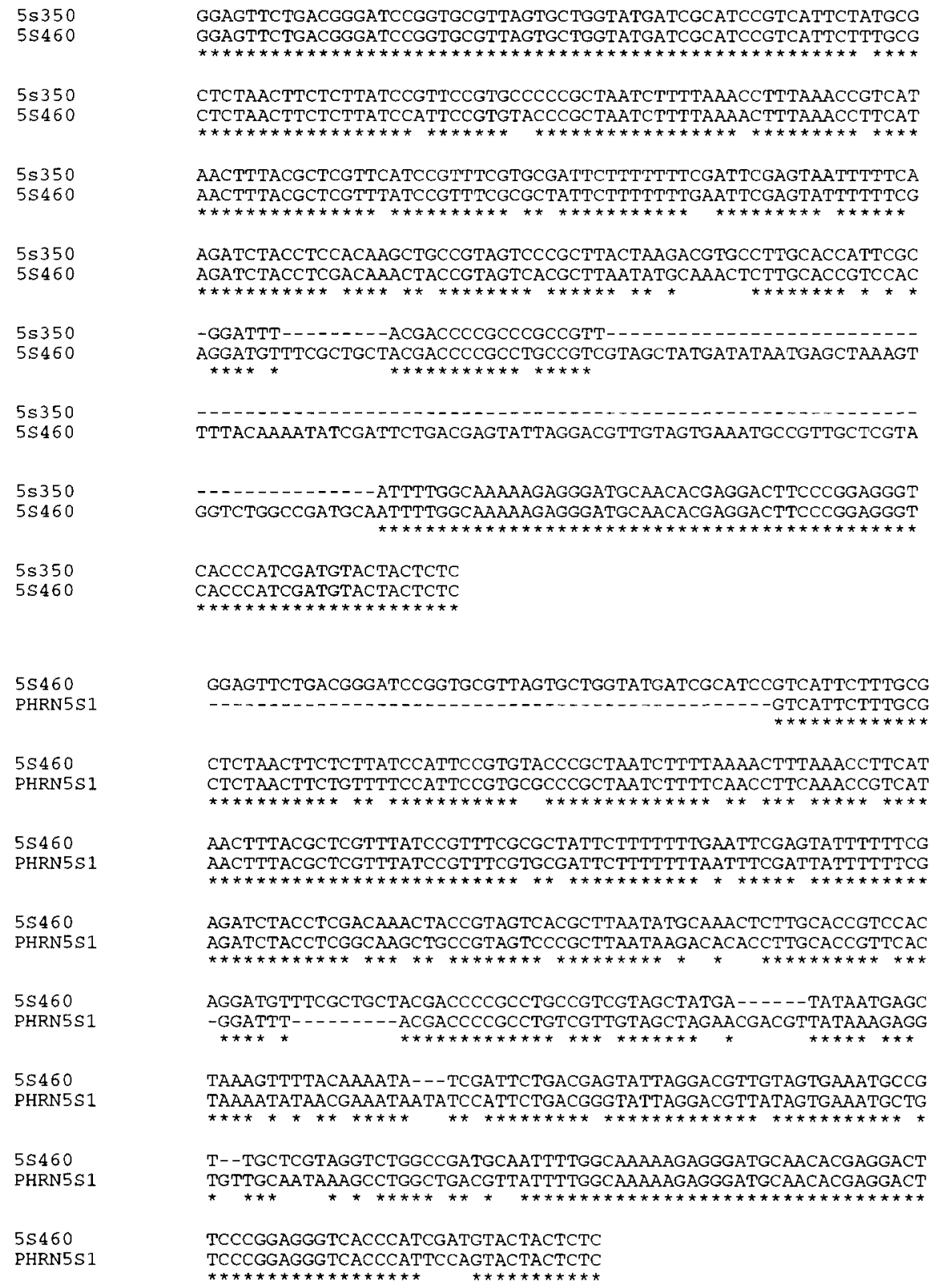

AACTTTACGCTCGTTCATCCGTTTCGTGCGATTCTTTTTTTCGATTCGAGTAATTTTTCA AACTTTACGCTCGTTTATCCGTTTCGCGCTATTCTTTTTTTTGAATTCGAGTATTTTTTCG

AGATCTACCTCCACAAGCTGCCGTAGTCCCGCTTACTAAGACGTGCCTTGCACCATTCGC $\underset{\star \star \star \star * \star}{\text { AGATCTACCTCGACAAACTACCGTAGTCACGCTTAATATGCAAACTCTTGCACCGTCCAC }}$

-GGATTT-...-..-ACGACCCCGCCCGCCGTTAGGATGTTTCGCTGCTACGACCCCGCCTGCCGTCGTAGCTATGATATAATGAGCTAAAGT

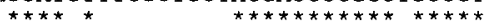

TTPACAAAATATCGATTCTGACGAGTATTAGGACGTTGTAGTGAAATGCCGTTGCTCGTA

GGTCTGGCCGATGCAATTTTTGGAAAAAGAGGGATGCAACACGAGGACTTCCCGGAGGGT

CACCCATCGATGTACTACTCTC

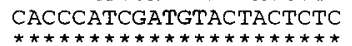

GGAGTTCTGACGGGATCCGGTGCGTTAGTGCTGGTATGATCGCATCCGTCATTCTTTGCG -

CTCTAACTTCTCTTATCCATTCCGTGTACCCGCTAATCTTTTAAAACTTTAAACCTTCAT CTCTAACTTCTGTTTTCCATTCCGTGCGCCCGCTAATCTTTTCAACCTTCAAACCGTCAT AACTTTACGCTCGTTTATCCGTTTCGCGCTATTCTTTTTTTGAATTCGAGTATTTTTTCG AACTTTACGCTCGTTTATCCGTTTCGTGCGATTCTTTTTTTAATTTCGATTATTTTTTCG AGATCTACCTCGACAAACTACCGTAGTCACGCTTAATATGCAAACTCTTGCACCGTCCAC

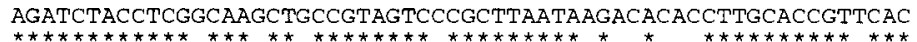
AGGATGTTTCGCTGCTACGACCCCGCCTGCCGTCGTAGCTATGA------TATAATGAGC -GGATTT-- - - ACGACCCCGCTGTCGTTGTAGCTAGAACGACGTTATAAAGAGG Ta

TAAAGTTTTACAAAATA---TCGATTCTGACGAGTATTAGGACGTTGTAGTGAAATGCCG TAAAATATAACGAAATAATATCCATTCTGACGGGTATTAGGACGTTATAGTGAAATGCTG T--TGCTCGTAGGTCTGGCCGATGCAATTTTGGCAAAAAGAGGGATGCAACACGAGGACT TGTTGCAATAAAGCCTGGCTGACGTTATTTTGGCAAAAAGAGGGATGCAACACGAGGACT

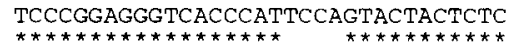

Fig 5. Sequence comparison between the published $5 \mathrm{~S}$ rDNA (phrn5s1, Frash et al, 1989) and the two amplified 350- and 460-bp repeat units.
The Southern analysis with the two amplified 5S rDNA probes was consistent with the results found by Kabbaj et al (1995) using the heterologous probe pBG13 from flax. Our results after a BamHI digestion revealed three variants of band patterns: $500 \mathrm{bp}$ for $P$ linearis, $460 \mathrm{bp}$ for $P$ integrifolia and $350 \mathrm{bp}$ for the other Petunia species. These results indicated that the common ancestor unit type probably corresponded to the BamHI/500 bp fragment found in $P$ linearis, which by successive deletions could have produced the 460- and 350-bp units. In all the Petunia species studied, the 5S rDNA region was especially polymorphic when cut by BamHI which produced a ladder of restriction fragments. This ladder in the BamHI-digested DNAs is prob- ably due to $\mathrm{C}$-methylation of the restriction sites as discussed for the diploid species of wheat (Dvorak et al, 1989). C-methylation in rDNA also affects EcoRI restriction sites (Ellis et al, 1989), which probably occurred in the Petunia species studied with the exception of $P$ linearis. Thus, a 500 -bp EcoRI band was only revealed in $P$ linearis. The size discrepancy observed between the amplified fragments and the restriction bands in $P$ linearis (460 bp versus $500 \mathrm{bp}$ ) could probably be due to a variation in the binding sites of the universal primers in comparison with the other Petunia species.

In all the Petunia wild species $(2 \mathrm{n}=14)$ and $P$ hybrida lines, the $18 \mathrm{~S}-5.8 \mathrm{~S}-25 \mathrm{~S}$ rDNA units 
Fig 6. Genomic DNAs (5 $\mu$ g per lane) of Petunia species digested with EcoRI (A), BamHI (B) and Dral (C) and probed with the 350-bp 5S rDNA fragment. Lane 1 and 11, 1-kb ladder (BRL); lane 2, $P$ linearis; lane $3, P$ integrifolia; lane, $4 P$ axillaris; lane 5, $P$ inflata; lane $6, P$ inflata $\times$ $P$ axillaris; lane 7, ST40; lane 8, TB1-3; lane 9, TLH7; lane 10, TLV1; lane 12, Raoul ladder (Appligene). The ladders of restriction bands with a periodicity of $500 \mathrm{bp}, 460 \mathrm{bp}$ and $350 \mathrm{bp}$ are marked with a circle, an arrow, and an arrowhead respectively. The 460 -bp 5S rDNA fragment revealed the same pattern not shown).
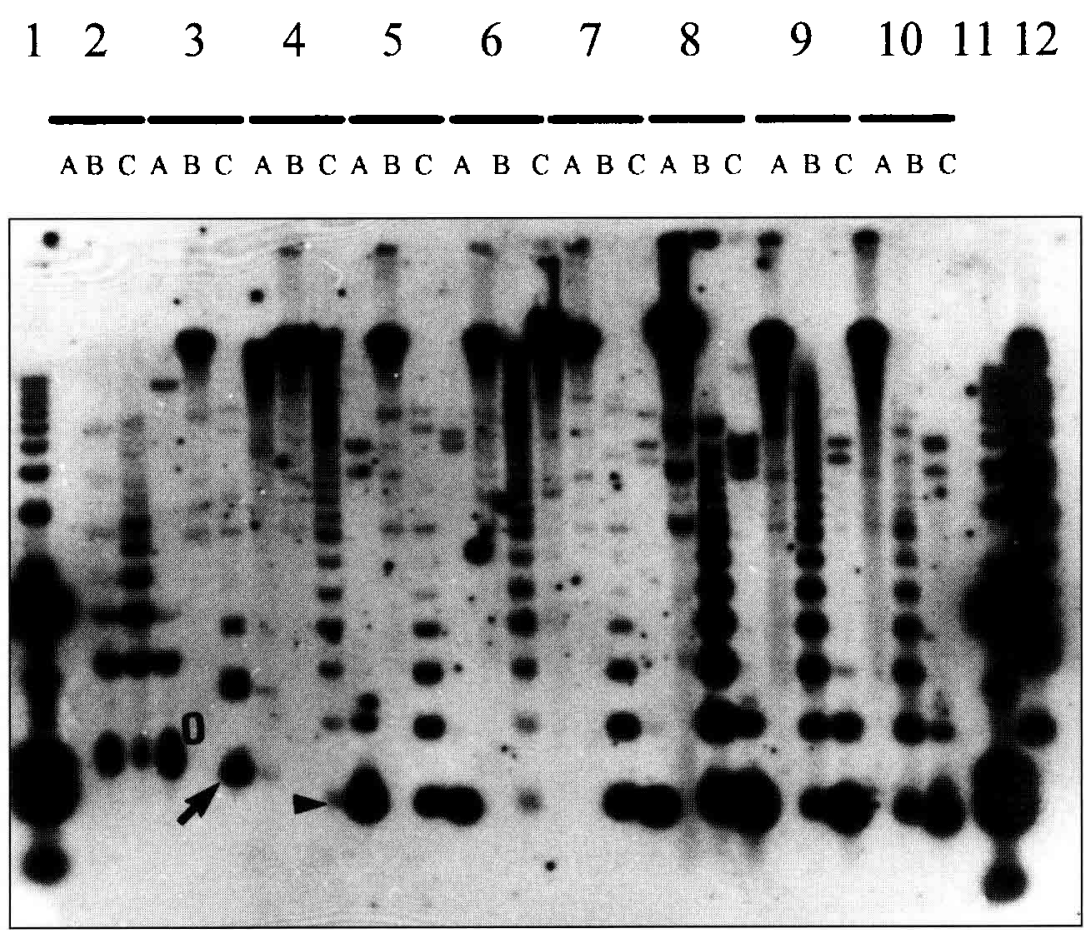

$\begin{array}{llllll}\text { I } & \text { II } & \text { III } & \text { IV/VII } & \text { V } & \text { VI }\end{array}$
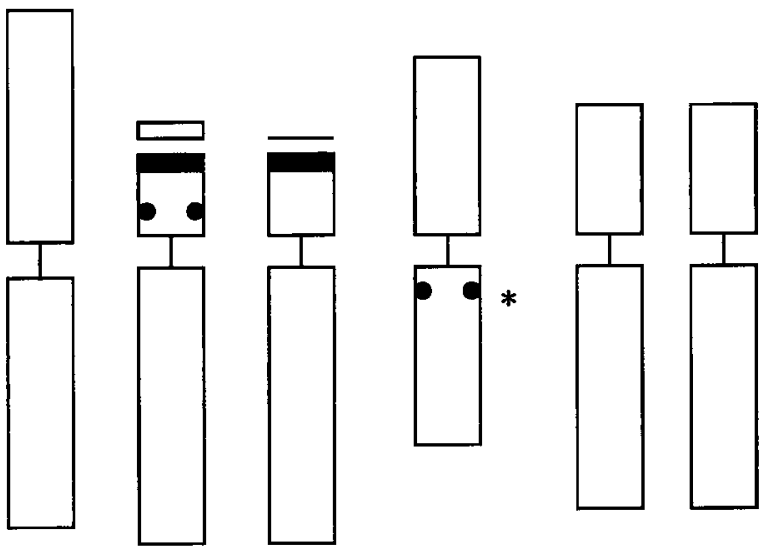

Fig 7. Ideogram of the Petunia species with $2 \mathrm{n}=14$ chromosomes as defined by Maizonnier (1971). The positions of the $5 \mathrm{~S}$ (shaded circles) and $18 \mathrm{~S}-5.8 \mathrm{~S}-25 \mathrm{~S}$ (shaded squares) rDNA genes are shown. * : corresponds to the second 5S rDNA locus found in the white flowered species.

were organized in two loci, one major and one minor. They were mapped, respectively, to chromosome II and to chromosome III. FISH analysis of interphase nuclei showed that the four sites seemed to be involved in transcription. Similar results were obtained with silver staining and 3-D studies of the gene position in the interphase nuclei (Montjin et al, 1997). In the Petunia species with $2 \mathrm{n}=18$ ( $P$ linearis and $P$ parviflora) only one locus for the $18 \mathrm{~S}-5.8 \mathrm{~S}-25 \mathrm{~S}$ rDNA genes was revealed. As the $P$ linearis and $P$ parviflora chromosomes cannot be discriminated by their length nor by their centromeric index, we suggest using the 18S-5.8S-25S rDNA gene clusters as a marker to identify this chromosome pair.

FISH results revealed that all the Petunia species studied have in common one 5S rDNA locus which was associated with the major 18S$5.8 \mathrm{~S}-25 \mathrm{~S}$ locus on the short arm of chromosome II. The adjacent localization of the $5 \mathrm{~S}$ and $18 \mathrm{~S}$ $5.8 \mathrm{~S}-25 \mathrm{~S}$ loci was also shown in some members of Triticeae (Castilho and Heslop-Harrison, 1995), in Hordeum species (De Bustos et al, 1996) and in Lolium species (Thomas et al, 1996). An additional 5S rDNA locus appeared in $P$ axillaris and $P$ parodii, and has also been revealed in the $P$ hybrida line TLH7, which was derived from back-crosses with $P$ axillaris (table I). This locus was carried, in a centromeric position, by chromosome IV or VII [as defined by Maizonnier (1971)]. A similar centromeric position of the 5S rDNA genes was also reported in tomato (Lapitan et al, 1991), in cultivated beet (Schmidt et al, 1994) and in cotton (Hanson et al, 1996).

The chromosomal localization of the 5S rDNA allowed us to distinguish two Petunia groups which corresponded to the separation according to corolla pigmentation. $P$ hybrida is believed to be an interspecific hybrid derived from crosses 

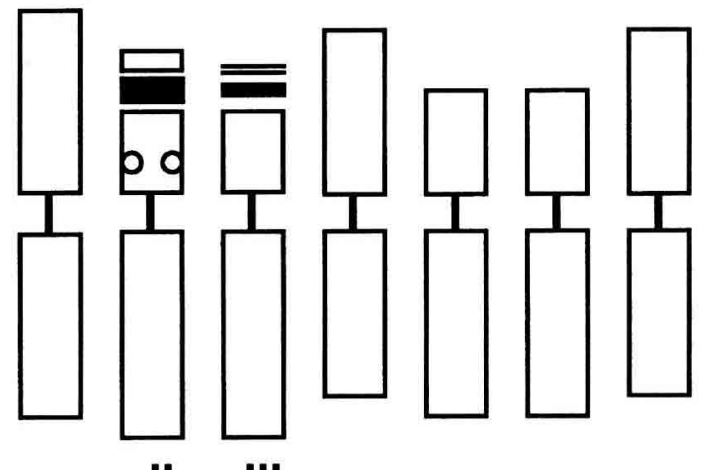

\section{$P$. integrifolia $2 n=14$}

II III

\section{Speciation}

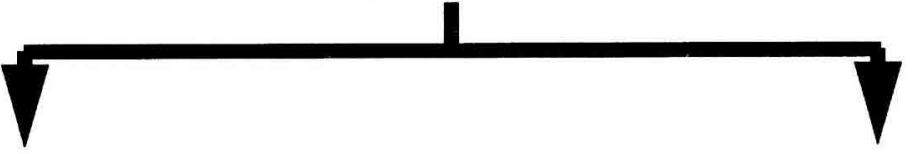

White flowers, $2 n=14$

$P$. axillaris

P. parodii
Coloured flowers, $2 n=14$

$P$. inflata

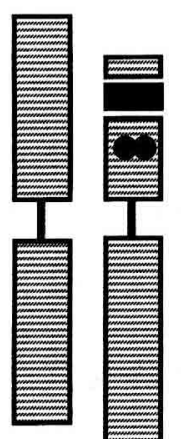

II

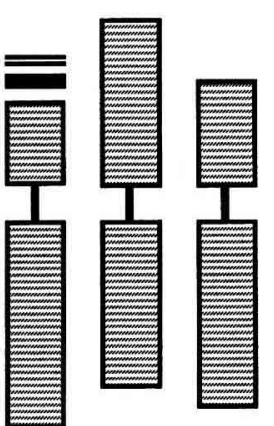

III

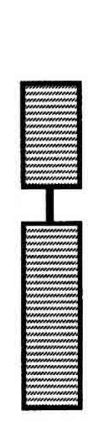

VII

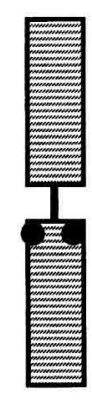

VII
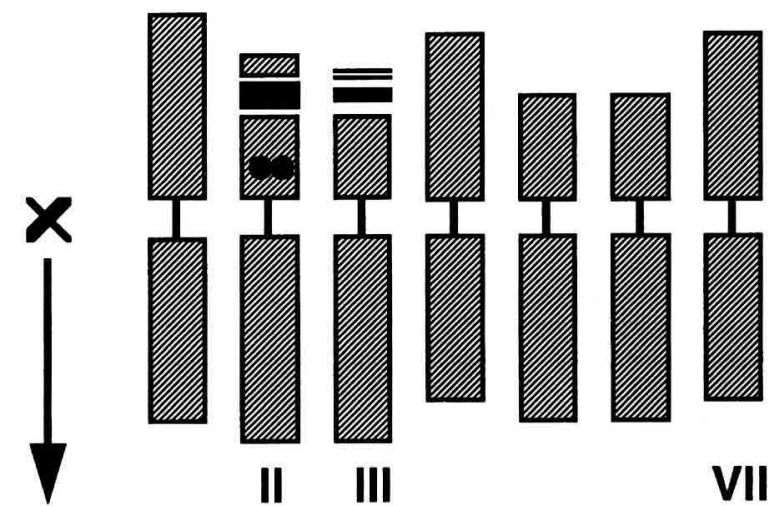

II III

VII

\section{0 years of selection}

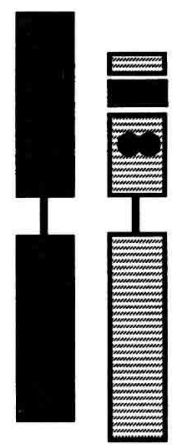

II

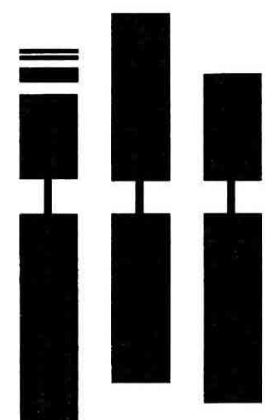

III

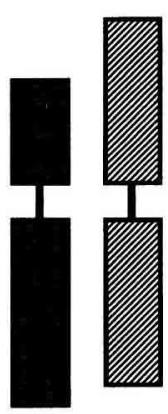

$P$. hybrida, $2 \mathrm{n}=14$

Fig 8. A schematic representation of the possible origin and genome organization of the $P$ hybrida lines studied as revealed by our results on the ribosomal RNA genes. $P$ integrifolia is separated from $P$ inflata.

: 18S-5.8S-25S rDNA sites), $\bigcirc 460$-bp 5S rDNA ( $P$ integrifolia) and $\bullet$ the 350-bp 5S rDNA (Petunia species with $2 \mathrm{n}=14$ ). chromosomal regions of white flowered group origin, chromosomal regions of coloured flowered group origin. In $P$ hybrida (except for line TLH7), chromosome II is believed to be inherited from the white flowered Petunia species, while chromosome VII is believed to be inherited from the coloured flowered Petunia species. 
performed 190 years ago between two genetic pools of white and coloured flowered Petunia species $(2 \mathrm{n}=14)$. Restriction polymorphism in rDNA genes (Kabbaj et al, 1995), RAPD and DAF studies (Peltier et al, 1994; Cerny et al, 1996) indicated that the most probable parents of $P$ hybrida were $P$ parodii and $P$ axillaris for the white flowered parent and $P$ inflata and $P$ integrifolia for the coloured flowered parent.

Our FISH results on the number and chromosome organization of rDNA clusters combined with PCR amplification and RFLP studies of the 5S rDNA lead us to suggest a possible model for the genome organization in $P$ hybrida (fig 8 ). The two BamHI- and EcoRI/500-bp 5S rDNA fragments specific to $P$ linearis as well as the presence of a single 18S-5.8S-25S rDNA locus allowed us to separate $P$ linearis from the other Petunia species. The question of whether $P$ linearis could be an ancestor of the other species remains open since some homology between $P$ linearis and the Petunia species with $2 \mathrm{n}=14$ was shown by genomic in situ hybridization (Benabdelmouna and Darmency, 1997), but taxonomists have proposed to transfer it to a different genus (Wisjman, 1990). In the Petunia species $(2 \mathrm{n}=14)$ with coloured flowers, $P$ integrifolia differs from $P$ inflata by the size of its 5 S rDNA repeat unit (460 bp versus $350 \mathrm{bp}$ ) while the number and localization of the rDNA loci are similar. In the $P$ hybrida lines, the exclusive presence of a 350-bp 5S rDNA repeat unit on chromosome II leads us to assume that chromosome II of $P$ integrifolia probably did not contribute to the genome of $P$ hybrida. This chromosome, which carries RAPD markers exclusively found in the white flowered Petunia species (Peltier et al, 1994), could be inherited from the white flowered species ( $P$ axillaris or $P$ parodii). All the $P$ hybri$d a$ lines studied, with the exception of the line TLH7, have lost the second 5S rDNA locus carried by the chromosome pair IV or VII, which indicates that this chromosome pair may be inherited from the coloured flowered species carrying only one $5 \mathrm{~S}$ rDNA locus. The RAPD markers mapped on chromosome VII were essentially inherited from the coloured species, chromosome IV being without any associated RAPD marker (Peltier et al, 1994). We propose that chromosome VII is the most probable candidate to carry the second 5S rDNA locus in the white flowered Petunia species.

Acknowledgements: We would like to thank D Van Tuinen and D Zickler for helpful comments, J Delbut for technical assistance and $\mathrm{C}$ Humbert from the CMAB, université de
Bourgogne, Dijon for his expertise in confocal microscopy observations.

\section{REFERENCES}

Appels R, GerlachWL, Dennis ES, Swift H, Peacock WJ (1980) Molecular and chromosomal organisation of DNA sequences coding for the ribosomal RNAs in Cereals. Chromosoma 78, 293-311

Appels R, Honeycut RL (eds) (1986) rDNA Evolution over a Billion Years. CRC Press, Boca Raton

Benabdelmouna A, Darmency MA (1997) Relationships between genomes of Petunia studied by genomic in situ hybridization. Genome (in press)

Bernatzky R, Tanksley SD (1986) Genetics of actinrelated sequences in tomato. Theor Appl Genet 72, 314-321

Castilho A, Heslop-Harrison JS (1995) Physical mapping of $5 \mathrm{~S}$ and $18 \mathrm{~S}-25 \mathrm{~S}$ rDNA and repetitive DNA sequences in Aegilops umbellulata. Genome 38, 91 96

Choumane W, Heizman P (1988) Structure and variability of nuclear ribosomal genes in the genus Helianthus. Theor Appl Genet 76, 481-489

Cordesse F, Cooke R, Tremoussaygue D, Grellet F, Delseny M (1993) Fine structure and evolution of the rDNA intergenic spacer in rice and other cereals. J Mol Evol 36, 369-379

Cox AV, Bennett MD, Dyer A (1992) Use of the polymerase chain reaction to detect spacer size heterogeneity in plant 5S-rRNA gene clusters and to locate such clusters in wheat (Triticum aestivum $\mathrm{L}$.). Theor Appl Genet 83, 684-690

De Bustos A, Cuadrado A, Soler C, Jouve N (1996) Physical mapping of repetitive DNA sequences and $5 \mathrm{~S}$ and $18 \mathrm{~S}-26 \mathrm{~S}$ rDNA in five wild species of the genus Hordeum. Chromosome Res 4, 491-499

Dvorak J, Zhang HB, Kota RS, Lassne, M (1989) Organization and evolution of the $5 \mathrm{~S}$ ribosomal RNA gene familly in wheat and related species. Genome 32, 1003-1016

Ellis THN, Delseny M, Lee D, Burcham KWG (1989) Methylated and under methylated rDNA repeats are interspersed at random in two higher plant species. Plant Mol Biol 14, 73-80

Flavel RB (1986) The structure and control of expression of ribosomal RNA genes. Plant Mol Cell Biol 3, 251-274

Fransz PF, Stan M, Montijn B, Ten Hoopen R, Wiegant J, Kooter JM, Oud O, Nanninga N (1996) Detection of single copy genes and chromosome rearrangements in Petunia hybrida by fluorescence in situ hybridization. Plant $J 9,767-774$

Frasch M, Wenzel W, Hess D (1989) The nucleotide sequence of $5 \mathrm{~S}$ rRNA genes and spacer regions of Petunia hybrida. Nucleic Acids Res 17, 2857 
Gamborg OL, Miller RAA, Ojima K (1968) Nutrient requierements of suspension cultures of soy bean root cells. Exp Cell Res 50, 151-158

Goldsbrough PB, Ellis THN, Cullis CA (1981) Organisation of the 5S RNA genes in flax. Nucleic Acids Res 9, 5895-5904

Goldsbrough PB, Ellis THN, Lomonossof GP (1983) Sequence variation and methylation of the 5S RNA genes. Nucleic Acids Res 10, 4501-4514

Hanson RE, Nurul Islam-Faridi M, Percival EA, Crane CF, Ji Y, McKnight TD, Stelly DM, Price HJ (1996) Distribution of $5 \mathrm{~S}$ and 18S-28S rDNA loci in a tetraploid cotton (Gossypium hirsutum L.) and its putative diploid ancestors. Chromosoma 105, 5561

Heslop-Harrison JS (1991) The molecular cytogenetics of plants. J Cell Sci 100, 15-21

Kabbaj A, Zeboudj F, Peltier D, Tagmount A, Tersac M, Dulieu H, Bervillé A (1995) Variation and phylogeny of the ribosomal DNA unit types and $5 \mathrm{~S}$ DNA in Petunia Jussieu. Genet Res Crop Evol 42, 311-325

Lapitan NLV, Ganal MW, Tanksley SD (1991) Organization of the $5 \mathrm{~S}$ ribosomal RNA genes in the genome of tomato. Genome 34, 509-514

Maizonnier D (1971) Utilisation des plantes haploides pour l'analyse du caryograme de Petunia hybrida Hort. Ann Amelio Plant 21, 257-264

Maniatis T, Fritsch EF, Sambrook J (1982) Molecular Cloning: a Laboratory Manual. Cold spring Harbor Laboratory, NY

Mascia PN, Rubenstein I, Phillips RL, Wang AS, Xiang LZ (1981) Localization of the 5 S rDNA genes and evidence for diversity in the $5 \mathrm{~S}$ rDNA region of maize. Gene 15, 7-20

Montijn BM (1997) Spatial organisation of ribosomal RNA genes in root meristems as studied by confocal microscopy. Academisch Proefschrift, Universteit van Amsterdam, Amsterdam, 77-99

Montijn MB, Houtsmuller AB, Oud JL, Nanninga N (1994) The spatial localization of $18 \mathrm{~S}$ rRNA genes, in relation to the descent of the cells, in the root cortex of Petunia hybrida. J Cell Sci 107, 457-467

Murphy G, Kavanagh T (1988) Speeding up the sequencing of double stranded DNA. Nucleic Acids Res 16, 5198

Pan WH, Houben A, Schlegel R (1993) Highly effective cell synchronization in plant roots by hydroxyurea and amiprosphos-methyl or colchicine. Genome 36, 387-390
Peltier D, Farcy E, Dulieu H, Bervillé A (1994) Origin, distribution and mapping of RAPD markers from wild Petunia species in Petunia hybrida Hort lines. Theor Appl Genet 88, 637-645

Rafalski JA, Wiewiorowski M, Soll D (1982) Characterization and nucleotide sequence of nuclear 5S RNA genes in yellow lupin (Lupinus luteus). Nucleic Acids Res 10, 7635-7642

Rogers SO, Bendich AJ (1987) Ribosomal RNA genes in plant: variability in copy number and in the intergenic spacer. Plant Mol Biol 9, 509-520

Saghai-Maroof MA, Soliman KM, Jorgensen RA, Allard RW (1984) Ribosomal DNA spacer length polymorphisms in barley: Mendelian inheritance, chromosomal location, and population dynamics. Proc Natl Acad Sci USA 81, 8014-8018

Schmidt T, Schwarzacher T, Heslop-Harrison JS (1994) Physical mapping of rRNA genes by fluorescent in situ hybridization and structural analysis of 5S rRNA genes and intergenic spacer sequences in sugar beet (Beta vulgaris). Theor Appl Genet 88, 629-636

Southern E (1975) Detection of specific sequences among DNA fragments separated by gel electrophoresis. J Mol Biol 98, 503-509

Thomas HM, Harper JA, Meredith MR, Morgan WG, Thomas ID Timms ET, King IP (1996) Comparison of ribosomal DNA sites in Lolium species by fluorescence in situ hybridization. Chromosome Res 4, 486-490

Van Tuinen D, Jacquot E, Zhao B, Gollotte A, Gianinazzi-Pearson V (1997) Synergistic coexistence of different arbuscular mycorrhizal fungi in root studied by $25 \mathrm{~S}$ rDNA-targeted nested-PCR. Appl Env Micro (in press)

Waldron J, Dansmuir P, Bedbrook J (1983) Characterization of the rDNA repeat units in the Mitchell Petunia genome. Plant Mol Biol 2, 57-65

White TJ, Burns T, Lee S, Taylor J (1990) Amplification and direct sequencing of fungal ribosomal RNA genes for phylogenetics. In: $P C R$ Protocols (MA Imis, JJ Gelfand, TJ White, eds), Academic Press, San Diego, CA

Wisjman HJW (1990) On the interrelationships of certain species of Petunia VI. New names for the species of Calibrachoa formerly included into Petunia (Solanaceae), Acta Bot Neerl 39, 101-102

Zeboudj F, Kabbaj A, Sossey-Alaoui K, Peltier D, Tagmount A, Racquin C, Darmency M, Maizonnier D, Dulieu H, Bervillé A (1994) Variation of ribosomal DNA and inheritance of polymorphisms in six Petunia hybrida hort lines. Agronomie 14, 1-11 